huge expenditure of scientists' time and taxpayers' money. Fortunately, perhaps, even though the (mainly acoustic) detection systems are complex the modern submarine is relatively safe in the ocean. Ross quotes a comparison between antisubmarine warfare and a game of baseball with the fielders blindfolded. And it is increasingly a game played between only two players, USA versus USSR, both of whom use the ocean as the location of their major weapon systems, their so-called 'second strike' capability. Because both nations have nearly undetectable submarines with frightening nuclear weapons, Ross argues that the opacity of the ocean deters them from starting a nuclear attack - an optimistic view.

If the opacity of sea water is important to submarines its combination of high density and low viscosity is fundamental to merchant shipping; surface ships remain the only practicable way of transporting heavy and bulky cargo over intercontinental distances. Next to military activity the shipping industry spends most on marine affairs (about $10^{11}$ dollars/year is said to go on building, maintaining and repairing ships). Ships and shipping have changed a great deal in recent decades: passenger liners are no more and cargo ships have become much more specialized, especially as regards the handling and stowage of their loads. They now need far smaller crews and in spite of much improved navigational aids collisions and other accidents still happen. Such catastrophes may lead to acute pollution of the Torrey Canyon type and one sympathizes with Ross's advocacy of "clear and positive control of ships, especially near or within coastal waters". But a comparison of aircraft and marine traffic control shows that this will need significant changes in the education and attitude of seafarers: this is a sociological problem which badly needs study.

The resources of the ocean with which most people are familiar are animal and mineral (it seems unlikely that the vegetable phytoplankton will be harvested in bulk, though seaweed is an important product and its cultivation a new and growing industry). There is much argument about the total amount of fish and related creatures that could be safely harvested perhaps $2 \times 10^{8}$ tons/year is an optimistic figure. But it seems clear that marine biological resources are not the answer to the basic food problem posed by half the world's population being short of protein. Poorly understood and rather ineffectively controlled, fishing is perhaps the classical example of a non-profit industry. There may be an opportunity to exploit hitherto untaken species (krill is the obvious example); one can improve processing so as to convert trash fish into palatable products; one can develop and improve aquaculture techniques. All these will help supplement the world's protein requirements but seem unlikely to make a

\section{Soil sugars for the soil scientist}

\section{Schnitzer}

Nature and Origin of Carbohydrates in Soils. By M. V. Cheshire. Pp. 216. (Academic: 1980.) £15.80, \$36.50.

ABOUT $10 \%$ of the organic matter in soils occurs as carbohydrates - mainly in the form of polysaccharides comprised of at least seven neutral, two acidic and two basic sugars - which originate from plant and animal remains and from microbial syntheses. From an agricultural point of veiw, their most important functions are to supply microorganisms with readily available food and to bind soil particles into stable aggregates which improve soil aeration, root development and ease of cultivation, and prevent erosion.

The first four chapters of this book deal with the composition and analysis of carbohydrates and polysaccharides in soils. Especially useful are recommended procedures for the hydrolysis and analysis of freed sugars, uronic acids and amino sugars by colorimetric, gas chromatographic and enzymatic methods. A

major contribution.

Mineral, as distinct from biological, marine resources provide a clearer problem. Most are not renewable so the problem is to find them, extract them and process them, without harming the environment. Here Dr Ross is on home ground, giving a clear account of the probability of exploiting the sediments of the Red Sea brine pools and of the possibility of using the better known manganese nodules. In shallower water of fshore hydrocarbons are already a major industry, and will be for decades. Their yearly value (about $4 \times 10^{8}$ dollars) already exceeds that of fisheries.

Marine pollution is a diffuse and illdefined subject. There is a great lack of information on sources, cycles and sinks of chemicals in the sea. Much of the most objectionable material comes from industrial sources, mainly in developed countries (the degree of marine pollution correlates closely with gross national product). So it would be possible, at a price, to control it at source. This is one of the points made strongly by the developing nations at the UN Conference on the Law of the Sea, and one can readily sympathize with their point of view. Not much interested in the military and shipping aspects, they are concerned to ensure that the industrialized nations do not gain a disproportionately large share of the (perhaps over-stated) marine resources. The scientific study of the ocean comes relatively low on their list of priorities (after agriculture, roads, hospitals, literacy and such) so they see little harm in the pace of problem in such analyses is that polysaccharides in soils appear to be chemically linked to proteins and humic materials; so far separation from humic materials has been more successful than from proteins.

The next section is concerned with the metabolism of carbohydrates in soils. Incubation experiments with ${ }^{14} \mathrm{C}$-labelled glucose show that while microorganisms can synthesize soil sugars, the overall composition of microbial polysaccharides differs from that of soil polysaccharides as a whole and can only account for a part of it. It is estimated that the live biomass constitutes only $2.5 \%$ of the weight of soil carbohydrates.

The author has made a very useful contribution by bringing together the essence of widely scattered literature published over a period of 85 years. To the best of my knowledge this is the first book to deal with carbohydrates in soil; its appearance will be welcomed by those interested in the chemistry, biology and management of soil organic matter.

M. Schnitzer is Program Leader of soil chemistry and biology research at the Chemistry and Biology Research Institute, Agriculture Canada, Ottawa.

marine research being slowed down. Even the so-called developed nations prefer to gain control over as much of the ocean and seabed as possible rather than to make it free for oceanographers to study the basic phenomena.

Ross ends with a chapter "Innovative Uses of the Ocean", including energy from the sea; climate and the ocean; fresh water from the sea; drugs from the sea; disposal of nuclear waste; research on satellite oceanography; the prospects for offshore islands. Again the chapter is too short to do justice to the variety of topics and the author has not been able to polish his writing sufficiently. Altogether the book, though superficially attractive, gives the impression that it would have been much improved by more attention to detail, both in text and illustration. The photographs are good but some of the map projections unfortunate; the text has confusing expressions and rather a lot of minor misprints, even in the prefatory poem (The Sea and the Hills, from Kipling's The Five Nations - and a good example of his sound and fury style it is).

No one could possibly disapprove of the author's motives - it would be marvellous if politicians and lawyers and admirals and (perhaps especially) multi-national moguls knew and cared more about the sea. But I fear it will need more than a book like this.

Henry Charnock is Professor of Physical Oceanography at the University of Southampton. 